\title{
Adaptive Teaching in STEM: Characteristics for Effectiveness
}

By: Melony Allen, Angela W. Webb \& $\underline{\text { Catherine E. Matthews* }}$

Allen, M., Webb, A.W., \& Matthews, C. (2016). Adaptive Teaching in STEM: Characteristics for Effectiveness. Theory Into Practice 55 (3), 217-224.

***(C) Taylor \& Francis. Reprinted with permission. No further reproduction is authorized without written permission from Taylor \& Francis. This version of the document is not the version of record. Figures and/or pictures may be missing from this format of the document. $* * *$

This is an Accepted Manuscript of an article published by Taylor \& Francis in Theory Into Practice on 29 April 2016, available online: http://dx.doi.org/10.1080/00405841.2016.1173994.

\begin{abstract}
:
This article defines the process of adaptive teaching in science, technology, engineering, and math (STEM). We assert that teachers who possess a well-developed STEM pedagogical content knowledge, a constructivist paradigm of teaching and learning, and an ability to draw on a vision while reflecting on and during teaching to help negotiate challenges are well positioned to engage in the process of adaptive teaching. This article acknowledges the valuable knowledge, skills, and dispositions that novice teachers bring with them as they enter the workforce. To illustrate the process of adaptive teaching in STEM, we use an in-depth case study of a novice teacher. Our conclusion offers a discussion of how teacher educators and those who provide professional development services during induction can best support teachers in their development of becoming adaptive, and therefore, effective.
\end{abstract}

Keywords: adaptive teaching | STEM | pedagogy | professional development | STEM educators

\section{Article:}

WE CONCEPTUALIZE adaptive teaching in science, technology, engineering, and mathematics (STEM) as a process that teachers initiate when they recognize and gauge their students' STEMrelated conceptual development, inquiry processes, and real-world connections and then maneuver their instruction to further develop these features of students' learning. An adaptive teacher may engage in this process during planning, while teaching, or after teaching as well as while using commercially developed or self-created curriculum materials (Allen, Matthews, \& Parsons, 2013). A proliferation of multiple understandings of STEM education exists (Breiner, Harkness, Johnson, \& Koehler, 2012). We view STEM education as intentionally merging the separate disciplines in order to solve real-world problems (Labov, Reid, \& Yamamoto, 2010; Sanders, 2012). In this way, STEM experiences are represented by a teacher when a combination of two or more of STEM-related disciplines are used to help students acknowledge or respond to dilemmas that naturally exist in today's society. Furthermore, like Crippen and Archambault (2012), we view inquiry as the signature pedagogy for STEM education. 
Drawing on research and theory, we argue that teachers who possess (a) a well-developed STEM pedagogical content knowledge (PCK; Saxton et al., 2014), (b) a constructivist paradigm of teaching and learning (Goodwin \& Webb, 2014), and (c) the ability to draw on a vision while reflecting on and during teaching to help negotiate challenges in their teaching contexts are well positioned to engage in the process of adaptive teaching. We highlight findings from an in-depth case study of a novice elementary teacher who we taught during her teacher preparation program and captured performances of and reasoning about adaptive teaching. We conclude with a discussion of how teacher educators and those who provide professional development services during induction can best address these three components (STEM PCK, constructivist paradigm of teaching and learning, and a vision for teaching during reflection to negotiate challenges) to better ensure that pre-service and novice STEM teachers possess the capacity to be adaptive, and therefore, effective.

\section{Conceptualizing STEM PCK}

PCK is a teacher characteristic associated with teacher quality (Hattie, 2009; Leinhardt, 1986; Shulman, 1986; Torff \& Sessions, 2009). This association is rooted in the notion that during planning, while teaching, or after teaching, teachers draw on their PCK to make critical decisions that impact students' learning (Kleickmann et al., 2013; Lee, 2010; Park, Jang, Chen, \& Jung, 2011; Shulman 1987). Specifically, PCK encompasses one's understanding of instructional strategies and representations, and students' misconceptions (Shulman, 1986). Since Shulman's initial work, teachers' subject-related PCK has emerged as a defining characteristic believed to impact students' learning and motivation (Alonzo, Kobarg, \& Seidel, 2012).

Drawing on the STEM PCK definition offered by Saxton et al. (2014), we conceptualize STEM PCK as teachers' knowledge of: (a) students' thinking about STEM-related topics, (b) instructional strategies for engaging students in inquiry processes, and (c) real-world STEMrelated connections. A teacher who has a well-developed knowledge base about what students know and are able to do and about what real-world connections exist can readily access this knowledge to make the necessary instructional moves. In other words, we view STEM PCK as teachers' knowledge in the aforementioned domains, rather than teachers' actions. A robust STEM PCK ensures that teachers have the necessary knowledge to recognize and gauge their students' STEM-related conceptual development, inquiry processes, and real-world connections to intentionally alter their instruction in productive ways.

\section{Constructivist Paradigm of Teaching and Learning: A Frame for Inquiry-Based Pedagogy}

Teachers who frame their ideas about teaching and learning within a constructivist paradigm share the following beliefs: (a) Students' learning is a result of the meanings they make of their experiences, (b) the personalization of teaching involves connecting to students' experiences and then providing spaces for students to develop and express ideas, and (c) the processes learners use in pursuit of knowledge and understanding are more important than simply accumulating facts (Shaw, Bayne, \& Lorelle, 2012). If one's paradigm compels behavior (Goodwin \& Webb, 2014), then teachers who possess a constructivist paradigm for teaching and learning position themselves as facilitators of learning, engage in self-reflection, and promote reflection among 
their students (Watts, 2011). Additionally, specific teaching and learning behaviors include using students' perspectives as cues for providing classroom experiences that ultimately emerge from students' sense-making of big ideas (Brooks, 1999).

The constructivist paradigm of teaching and learning aligns exceptionally well with using an inquiry-based pedagogy for STEM education. Just as multiple understandings of STEM education exist, multiple understandings about how best to define inquiry also exist (see HmeloSilver, Duncan, \& Chinn, 2007). To conceptualize inquiry, we draw upon the extensive analysis of literature conducted by Furtak, Seidel, Iverson, and Briggs (2012), in which they identified cognitive and guidance dimensions of inquiry-based instruction. The cognitive dimension encompasses the conceptual, epistemic, social, and procedural domains of scientific knowledge and the generation of such knowledge. The guidance dimension addresses to what extent teachers or students initiate inquiry activities.

\section{Negotiating Challenges in the Teaching Context: Becoming Reflective Visionaries}

Davis, Petish, and Smithey (2006) emphasized the importance of reflectiveness, identity, personal history, and self-efficacy in the induction of STEM teachers who are poised to engage in the process of adaptive teaching. Being a reflective practitioner-and thus able to negotiate challenges faced in teaching - requires both reflection on and in practice (Schön, 1987), in a purposeful way that conveys the continuous process of teacher learning throughout his or her career (Zeichner \& Liston, 1996). Negotiating the challenges faced in various teaching contexts is inherent to being a reflective teacher who

examines, frames, and attempts to solve the dilemmas of classroom practices; is aware of and questions the assumptions and values he or she brings to teaching; [and] is attentive to the institutional and cultural contexts in which he or she teaches. (Zeichner \& Liston, 1996, p. 6)

Throughout their preservice years, teachers are taught research-based ways in which to teach STEM. Although instructional models and paradigms are often upheld, sometimes they waiver in translation to the rough and tumble of day-to-day classroom practice. Challenges arise as STEM teachers are faced with translating theory into practice to teach diverse groups of students (Teo \& Ke, 2014) within a specific school context (Kelly, Gningue, \& Qian, 2015). As novice teachers grapple with their instruction, those who are able to draw on their visions (Hammerness, 2006) can negotiate and overcome instructional challenges (Vaughn \& Faircloth, 2011). Envisioning the kind of teacher one desires to become while reflecting on and in practice assists in the process of becoming an adaptive teacher by helping the novice teacher negotiate challenging instructional situations.

In the next section, we present Amelia, who was a novice fourth-grade teacher when we examined the nature of her adaptive teaching in science. We share Amelia's story here to highlight and celebrate the valuable knowledge, skills, and dispositions that novice teachers hold. Focusing on a teacher who has recently begun teaching allows us to identify dimensions of teacher development that might be more readily attended to during teacher preparation and induction. We are inspired by Amelia. Her story reminds us that teaching matters; good teachers 
make a difference; and novice teachers can be, and are, good teachers when they attend to adaptive teaching.

\section{Amelia: An Adaptive Novice Teacher}

Amelia has an extensive background in science. During high school, she excelled in elective and advanced placement science courses. During her teacher education program, she had many science experiences as she worked towars her state Environmental Education Certification. Additionally, Amelia received the Teaching Fellow award, a highly competitive state-sponsored scholarship.

Amelia became a teacher because she wanted to positively impact youth. She envisioned helping students realize their strengths and their potential, and wanted them to know enough about the world to help them make decisions about who and what they wanted to become. We know this because, as preservice teacher educators, we asked our students about their visions of teaching and then, each time we completed an observation of their work in internships or student teaching, over a period of years, we asked them to reflect on their lessons in terms of their vision for teaching.

Nestled in Amelia's vision of teaching was a clear understanding of the state-mandated curriculum she was expected to teach. She used the state curriculum as a framework when she implemented a kit-based science unit on magnetism and electricity. The goals of the unit on magnetism and electricity focused on students' development of observation and descriptive skills as well as providing evidence-based explanations. The state science curriculum for 4th grade suggested that magnetism and electricity are intertwined topics and that students should learn to make observations and conduct investigations to build an understanding of magnetism and electricity.

The main focus of both the unit and state-mandated curriculum was science. However, through inquiry-based instruction, Amelia had multiple opportunities to combine math and engineering for her students while making connections to the real world. These factors allowed us to investigate Amelia's adaptive teaching in STEM. For example, math was incorporated when students collected and represented data as they learned about the magnetic force. Students engaged in engineering practices as they created circuits, explored items that were good conductors and insulators, and built electromagnets.

The first author observed Amelia teach the entire unit and Amelia provided insight about why and how she engaged in adaptive teaching through daily pre- and postlesson interviews. We found that Amelia encouraged students to work together to solve problems, complete explorations, and conduct investigations. She also watched for learning to emerge as students tinkered with materials and ideas. She listened in on the conversations that abounded in her classroom and insisted that students talked through their thinking and knowing, all while prompting them to reflect on their previous experiences.

For example, while teaching Amelia noticed that students were confused about which types of metals are magnetic. She redistributed a collection of magnetic and nonmagnetic objects and a 
magnet and instructed students to explore and discuss the commonalities among the magnetic items. Amelia explained that these instructional moves helped students to understand that magnets only attract objects with iron.

In another lesson, she noticed that groups were not using a common procedure to conduct an experiment to determine the strengths of various magnets. Amelia stopped the class and told students to "play around with breaking the magnetic force to figure out a good way to do this that we can all agree on." After students worked in their groups, she orchestrated a class discussion that promoted reflection among her students about how to establish a standard procedure. In a postlesson interview, she stated that she "wanted the data collected by students within their groups to be compared across the class." At this time, she also decided to revisit this in the next lesson to help students further understand that a fair test was necessary so data can be compared. When asked about why this was important, Amelia explicitly connected this adaptation to her vision:

I think it has a lot to do with my vision. Last time this (referring to the curriculum materials) was my guide and I used it thinking that I couldn't go wrong. But this time I want it to be more inquiry based and I want them (students) to get it. I feel like this time I'm doing more of what I want to do than what I did last time.

While planning and implementing the unit, Amelia thought about how to connect students' learning to the real world. For example, when she recognized students' comments about needing electricity to survive, she prompted students to consider whether electricity is needed or is part of an advanced technological society. As a result, students bantered back and forth, explained their position and ultimately realized that electricity was not needed for survival, but instead was a kind of technology that met a human desire. When individual students made real-world connections, either through comments or questions, she highlighted these connections for the entire class while she prompted students to reflect on previous learning. In fact, Amelia believed that students' questions were the most important part of a lesson "because those are the questions they have, based on what they know. I think a good way to help them understand is by making a real-world connection. They need to see how learning connects to their lives.”

Amelia, an intelligent and reflective novice teacher, demonstrated adaptive teaching in STEM by promoting students' conceptual development, inquiry, and real-world connections. She was a teacher whose PCK was well developed and whose instruction was situated in a constructivist paradigm. She was focused and committed to her vision and drew upon her vision for teaching to help her negotiate challenging instructional situations. Amelia's story helps uncover the characteristics of an adaptive, and therefore effective, novice teacher.

\section{Discussion}

We have argued that teachers who possess (a) well-developed STEM PCK (Saxton et al., 2014), (b) a constructivist approach to STEM teaching and learning, and (c) the ability to draw on their vision while reflecting on and during teaching to help negotiate challenges in their teaching context are well positioned to engage in the process of adaptive teaching. We offered and discussed Amelia's science teaching as an illustrative case of an adaptive novice teacher who 
possessed the aforementioned knowledge, skills, and dispositions. To conclude our discussion of adaptive teaching in STEM, we now consider how teacher educators and those who provide professional development services during induction can best foster these components to better ensure that preservice and novice STEM teachers possess the capacity to be adaptive, and thus, effective.

In an extensive review and analysis of PCK, Kind (2009b) distinguished components of PCK development: solid subject matter knowledge, classroom experience, and well-adjusted emotional attributes. STEM teachers come to possess good subject matter knowledge through their content degrees and gain classroom experiences through field-based components of their teacher education courses. Well-adjusted emotional attributes, such as self-confidence and receptiveness to feedback (see Kind, 2009a), can also be fostered during the sense-making and reflective opportunities in field-based experiences. Teacher educators and professional development providers can promote the development of PCK in preservice and novice STEM teachers by adopting a transformative model of PCK in which a mechanism exists for developing PCK as a unique type of knowledge (i.e., separate from, but built on, subject matter knowledge), making explicit what PCK is (see Nilsson \& Loughran,2012), and attending to the emotional aspects of becoming and being a STEM teacher (Kind, 2009b).

As previously discussed, STEM teachers who frame their perspectives on teaching and learning within a constructivist paradigm position themselves as facilitators of learning, engage in selfreflection, and foster reflection among their students (Watts, 2011). However, "constructivism in practice includes the ambiguities, contradictions, and compromises that are part of implementing constructivist” (Windschitl, 2002, p. 132), and by extension inquiry-based, instruction. Teacher educators and professional development providers, then, need ways to support STEM teachers' implementation of, and critical reflection on, the constructivist paradigm and inquiry-based STEM instruction. To accomplish this, Clough, Berg, and Olson (2009) advanced a decisionmaking framework to facilitate bridging the chasm between research and practice related to educational perspectives and approaches such as constructivism. As they explained, "The overarching intent of the Decision-Making Framework is to illustrate that all teacher decisions regarding science content, tasks, activities, materials, models, strategies, and teacher behaviors should be made in light of desired goals for students and how students learn” (Clough et al., 2009, p. 829). By elucidating complex interactions among student goals, student actions, knowledge of the learner, and key synergetic teacher decisions, the decision-making framework has great utility in teacher education and induction to scaffold and help preservice and novice STEM teachers make sense of educational research and understand how crucial teacher decisions interact with student learning (Clough et al., 2009). This work can occur explicitly in preservice teacher education methods courses, mentoring relationships, and in-service professional development.

Mentoring is important in promoting STEM teachers' use of constructivist and inquiry-based teaching. However, mentoring focused on dialogue about teaching and learning (Harrgarty, Postlethwaite, Diment, \& Ellins, 2011) can also enable reflectiveness (Feiman-Nemser, 2001), foster robust identities (Webb, 2015), and promote agency (Webb, 2015) that facilitates the negotiation of challenges in the teaching context. Described by Feiman-Nemser (2001), "educative mentoring rests on an explicit vision of good teaching and an understanding of 
teacher learning" (p. 18), and "has the potential to foster powerful teaching and to develop the dispositions and skills of continuous improvement” (p. 28). Such mentoring, though, does not only occur after STEM teachers enter the teaching profession; teacher education faculty, university supervisors, and field-based mentor teachers can and should also engage pre-service STEM teachers in educative mentoring.

Teacher educators may begin by requiring candidates to envision the teacher they want to become and then hold them accountable for this development. Once novices enter the teaching profession, professional development providers should work to ensure that mentors are carefully selected, trained, and well supported to boost the learning of novice teachers (Bartell, 2005; Berry, Hopkins-Thompson, \& Hoke, 2002; Darling-Hammond \& Baratz-Snowden, 2005; Moir, 2005).

Preservice and novice teachers who possess well-developed STEM PCK, a constructivist paradigm of teaching and learning, and an ability to use their vision during reflection to help negotiate challenges in their teaching contexts are equipped to recognize and gauge their students' STEM-related conceptual development, inquiry processes, and real-world connections and then maneuver their instruction to further develop these features of students' learning. That is, they are poised to be adaptive, and therefore, effective teachers.

\section{References}

Allen, M. H., Matthews, C. E., \& Parsons, S. A. (2013). A second-grade teacher's adaptive teaching during an integrated science-literacy unit. Teaching and Teacher Education, 35, 114125.

Alonzo, A. C., Kobarg, M., \& Seidel, T. (2012). Pedagogical content knowledge as reflected in teacher-student interactions: Analysis of two video cases. Journal of Research in Science Teaching, 49, 1211-1239.

Bartell, A. C. (2005). Cultivating high-quality teaching through induction and mentoring. Thousand Oaks, CA: Corwin.

Berry, B., Hopkins-Thompson, T., \& Hoke, M. (2002). Assessing and supporting new teachers: Lessons from the Southeast. Chapel Hill, NC: Southeast Center for Teaching Quality at the University of North Carolina.

Breiner, J. M., Harkness, S. S., Johnson, C. C., \& Koehler, C. M. (2012). What is STEM? A discussion about conceptions of STEM in education and partnerships. School Science and Mathematics, 112, 3-11.

Brooks, J. G. (1999). In search of understanding: The case for constructivist classrooms. Alexandria, VA: Association for Supervision and Curriculum Development.

Clough, M. P., Berg, C. A., \& Olson, J. K. (2009). Promoting effective science teacher education and science teaching: A framework for teacher decision-making. International Journal of Science and Mathematics Education, 7, 821-847. 
Crippen, K. J., \& Archambault, L. (2012). Scaffolded inquiry-based instruction with technology: A signature pedagogy for STEM education. Computers in the Schools, 29, 157-173.

Darling-Hammond, L. \& Baratz-Snowden (Eds.). (2005). A good teacher in every classroom. San Francisco, CA: Jossey-Bass.

Davis, E. A., Petish, D., \& Smithey, J. (2006). Challenges new science teachers face. Review of Educational Research, 76, 607-651.

Feiman-Nemser, S. (2001). Helping novices learn to teach: Lessons from an exemplary support teacher. Journal of Teacher Education, 52, 17-30.

Furtak, E. M., Seidel, T., Iverson, H., \& Briggs, D. C. (2012). Experimental and quasiexperimental studies of inquiry-based science teaching: A meta-analysis. Review of Educational Research, 82, 300-329.

Goodwin, D., \& Webb, M. A. (2014). Comparing teachers' paradigms with the teaching and learning paradigm of their state's teacher evaluation system. Research in Higher Education Journal, 25, 1-11.

Hammerness, K. (2006). Seeing through teacher's eyes: Professional ideals and classroom practices. New York, NY: Teachers College Press.

Haggarty, L., Postlethwaite, K., Diment, K., \& Ellins, J. (2011). Improving the learning of newly qualified teachers in the induction year. British Educational Research Journal, 37, 935-954. doi:10.1080/01411926.2010.508513.

Hattie, J. (2009). Visible learning: A synthesis of over 800 meta-analyses relating to achievement.London, England: Routledge.

Hmelo-Silver, C. E., Duncan, R. G., \& Chinn, C. A. (2007). Scaffolding and achievement in problem-based and inquiry learning: A response to Kirschner, Sweller, and Clark (2006). Educational Psychologist, 42, 99-107.

Kelly, A. M., Gningue, S. M., \& Qian, G. (2015). First-year urban mathematics and science middle school teachers: Classroom challenges and reflective solutions. Education and Urban Society, 47, 132-159.

Kind, V. (2009a). “A conflict in your head”: An exploration of trainee science teachers' subject matter knowledge development and its impact on teacher self-confidence. International Journal of Science Education, 31, 1529-1562.

Kind, V. (2009b). Pedagogical content knowledge in science education: perspectives and potential for progress. Studies in Science Education, 45, 169-204. 
Kleickmann, T., Richter, D., Kunter, M., Elsner, J., Besser, M., Krauss, S., \& Baumert, J. (2013). Teachers' content knowledge and pedagogical content knowledge: The role of structural differences in teacher education. Journal of Teacher Education, 64, 90-106.

Labov, J. B., Reid, A. H., \& Yamamoto, K. R. (2010). Integrated biology and undergraduate science education: a new biology education for the twenty-first century? CBE-Life Sciences Education, 9, 10-16.

Lee, J. (2010). Exploring kindergarten teachers' pedagogical content knowledge of mathematics. International Journal of Early Childhood, 42, 27-41.

Leinhardt, G. (1986). Expertise in mathematics teaching. Educational Leadership, 43, $28-33$.

Moir, E. (2005). Launching the next generation of teachers: The New Teacher Center's model for quality induction and mentoring. In H. Portner (Ed.), Teacher mentoring and induction: The state of the art and beyond (pp. 59-73). Thousand Oaks, CA: Corwin Press.

Nilsson, P., \& Loughran, J. (2012). Exploring the development of pre-service science elementary teachers' pedagogical content knowledge. Journal of Science Teacher Education, 23, 699-721.

Park, S., Jang, J. Y., Chen, Y. C., \& Jung, J. (2011). Is pedagogical content knowledge (PCK) necessary for reformed science teaching? Evidence from an empirical study. Research in Science Education, 41,245-260.

Sanders, M. (2012). Integrative STEM education as 'best practice'. Explorations of Best Practice in Technology, Design and Engineering Education, 2, 102-117.

Saxton, E., Burns, R., Holveck, S., Kelley, S., Prince, D., Rigelman, N., \& Skinner, E. A. (2014). A common measurement system for K-12 STEM education: Adopting an educational evaluation methodology that elevates theoretical foundations and systems thinking. Studies in Educational Evaluation, 40, 18-35.

Schön, D. (1987). Educating the reflective practitioner. San Francisco, CA: Jossey-Bass.

Shaw, B. M., Bayne, H., \& Lorelle, S. (2012). A constructivist perspective for integrating spirituality into counselor training. Counselor Education and Supervision, 51, 270-280.

Shulman, L. S. (1986). Those who understand: Knowledge growth in teaching. Educational Researcher, 15, 4-14.

Shulman, L. S. (1987). Knowledge and teaching: Foundations of the new reform. Harvard Educational Review, 57, 1-22.

Teo, T. W., \& Ke, K. J. (2014). Challenges in STEM teaching: Implications for preservice and inservice teacher education program. Theory into Practice, 53, 18-24. 
Torff, B., \& Sessions, D. (2009). Principals' perceptions of the causes of teacher ineffectiveness in different secondary subjects. Teacher Education Quarterly, 127-148.

Vaughn, M., \& Faircloth, B. (2011). Understanding teacher visioning and agency during literacy instruction. In J. V. Hoffman, D. Shallert, C. Fairbanks, J. Worthy, \& B. Maloch (Eds.), 60th Yearbook of the National Reading Conference (pp. 309-323). Oak Creek, WI: National Reading Conference.

Villani, S. (2002). Mentoring programs for new teachers: Models of induction and support. Newbury Park, CA: Corwin.

Watts, R. E. (2011). Embracing both a constructivist counseling approach and a specific religious tradition: Is it a leap of faith? Counseling and Values, 56, 3-9.

Webb, A. W. (2015). Creating awareness of science teacher identity: The importance of who newly hired teachers of science are expected to be and who they become during induction. In J. A. Luft \&S. Dubois (Eds.), Newly hired teachers of science: A better beginning (pp. 99112). Boston, MA:SensePublishers.

Windschitl, M. (2002). Framing constructivism in practice as the negotiation of dilemmas: An analysis of the conceptual, pedagogical, cultural, and political challenges facing teachers. Review of Educational Research, 72, 131-175.

Zeichner, K. M., \& Liston, D. P. (1996). Reflective teaching: An introduction. Mahwah, NJ: Erlbaum.

\section{Additional Resources}

1. Strong, M. (2009). Effective teacher induction and mentoring: Assessing the evidence. New York, NY: Teachers College.

In this book, Michael Strong examines thoroughly research on teacher induction and retention to provide a history of mentoring and induction. Specifically, he assesses research to glean what is known about teacher induction as it relates to teacher retention, the development of teaching practices, effects on student achievement, and the costs and benefits of mentoring and induction programs. Strong also highlights what still needs to be learned in the areas of mentoring and induction.

2. Campoy, R. W. (2005). Case study analysis in the classroom: Becoming a reflective teacher. Thousand Oaks, CA: Sage.

In this book, Renee Campoy discusses how to use case studies to reflect on and solve classroom problems. She introduces the reader to the process of reflective problem solving and the importance of developing a cogent educational philosophy. Additionally, Campoy includes case 
studies related to students with exceptionalities; curriculum, instruction, and assessment; and classroom and school contexts that are appropriate for use and discussion with pre-service and novice teachers.

3. Mascil: Mathematics and Science for Life web site, http://www.mascil-project.eu.

This European Union Seventh Framework Programme-funded web site brings together 18 partners from 13 countries to promote inquiry-based teaching in primary and secondary schools. In addition to valuable classroom materials, the site includes professional development tool.

\footnotetext{
${ }^{*}$ Melony Allen, PhD, is at Georgia Southern University. Angela W. Webb, PhD, is at Louisiana State University. Catherine E. Matthews, PhD, is at the University of North Carolina at Greensboro.
} 